\title{
Effect of the cyclooxygenase-2 inhibitor tenoxicam on pentylenetetrazole-induced epileptic seizures in rats
}

\author{
Siklooksijenaz-2 inhibitörü tenoksikam'ın \\ pentilentetrazol ile oluşturulan epileptik nöbetler \\ üzerine etkisi
}

\section{Erkan Gumus ${ }^{1}$, Ahmet Sevki Taskıran², Hacer Aybike Toptas ${ }^{3}$, Özge Güney ${ }^{3}$, Rukiye Kutlu ${ }^{3}$, Handan Gunes ${ }^{2}$, Ercan Ozdemir², Gokhan Arslan²}

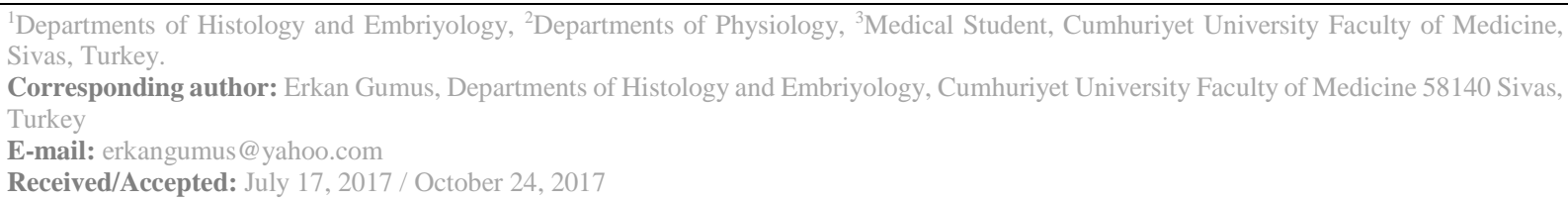

\section{SUMMARY}

Objective: Epilepsy is a short-term paroxysmal disturbances of brain functions observed between sudden, abnormal and hypersynchronization discharges and seizures of a group of neurons in the central nervous system. The nonsteroidal anti-inflammatory tenoxicam is chemical agent that selectively inhibits type 2 cyclooxygenase (COX2), which converts arachidonic acid to prostaglandins (PGs). The aim of this study was to investigate the effect of the cyclooxygenase-2 inhibitor tenoxicam on pentylenetetrazole on epileptic seizures. Method: Eighteen Wistar Albino male rats $(220 \pm 20 \mathrm{~g}$ ) were divided into three groups: control ( $\mathrm{n}=6), 10 \mathrm{mg} / \mathrm{kg} / \mathrm{day}$ tenoxicam $(\mathrm{n}=6)$ and, $20 \mathrm{mg} / \mathrm{kg} /$ day tenoxicam $(\mathrm{n}=6)$. Tenoxicam was administered intramuscularly for ten days. On the tenth day, pentylenetetrazol (PTZ) was injected intraperitoneally at $70 \mathrm{mg} / \mathrm{kg}$ after 45 minutes of drug administration and the animals were observed for $30 \mathrm{~min}$. Stages were determined according to the Racine seizure scale (RC) and the first myoclonic jerk time (FMJ) was recorded in seconds. After completing procedure, whole brain tissues were removed and stained with toluidine blue stain. The number of dark neurons with chromatin aggregation in hypocampal CA1 and dentate gyrus (DG) was determined as percentage. Results: Epileptic behavior were evaluated according to the RC, $10 \mathrm{mg} / \mathrm{kg}$ of tenoxicam significantly reduced the seizure stage compared to the control $(\mathrm{p}<0,05)$. In addition, $10 \mathrm{mg} / \mathrm{kg}$ tenoxicam significantly increased the FMJ compared to the control $(\mathrm{p}<0,05)$. According to the histopathological findings, neuronal damage was increased in CA1 region of $20 \mathrm{mg} / \mathrm{kg}$ of tenoxicam group compared to control, whereas neuronal damage was reduced significantly in the dentate gyrus of $10 \mathrm{mg} / \mathrm{kg}$ and $20 \mathrm{mg} / \mathrm{kg}$ of tenoxicam groups $(\mathrm{p}<0,05)$.

Conclusions: This study shows that dose-dependent administration of tenoxicam might have a potential to reduce epileptic seizures and post-seizure neuron damage. Keywords: Epilepsy, cyclooxygenase-2 inhibitor, tenoxicam, pentylenetetrazole 
enzimini selektif olarak inhibe eden kimyasal bir ajandır. Bu çalışmanın amacı siklooksijenaz-2 inhibitörü tenoksikam'ın pentilentetrazol ile oluşturulan epileptik nöbetlere üzerine etkisini araştırmaktır.

Yöntem: Çalışmamızda 18 tane 220-240 gr Wistar Albino erkek sıçan kullanılmıştır. Hayvanlar kontrol (n=6), 10 $\mathrm{mg} / \mathrm{kg} /$ gün tenoksikam ( $\mathrm{n}=6$ ) ve $20 \mathrm{mg} / \mathrm{kg} /$ gün tenoksikam ( $\mathrm{n}=6$ ) olmak üzere üç gruba ayrıldı. On gün süre ile kontrol grubuna çözücü ve diğer iki gruba belirtilen dozlarda tenoksikam intramusküler olarak uygulandı. Onuncu gün ilaç uygulamalarından $45 \mathrm{dk}$ sonra pentilentetrazol (PTZ) $70 \mathrm{mg} / \mathrm{kg}$ intraperitoneal olarak enjekte edildi. Hayvanlar $30 \mathrm{dk}$ boyunca gözlemlendi. Racine nöbet skalasına göre evreleri belirlendi ve ilk miyoklonik jerk zamanı (FMJ) saniye olarak kaydedildi. İşlem bitiminden sonra hayvanların beyin dokuları alındı. Beyin dokuları rutin histolojik takip sonrası toluidin blue boyası ile boyanandı. Hipokampüste CA1 ve dentat girus bölgelerinde nöronal hasarı gösteren 'Dark nöron' sayıları yüzde olarak belirlendi.

Bulgular: Epileptik davranış sonuçları Racine nöbet skalasına (RC) göre değerlendirildiğinde, $10 \mathrm{mg} / \mathrm{kg}$ tenoksikam kontrole göre nöbet evresini anlamlı olarak azalttı $(\mathrm{p}<0,05)$. Ayrıca $10 \mathrm{mg} / \mathrm{kg}$ tenoksikam kontrole göre ilk miyoklonik jerk zamanını anlamlı olarak arttırdı $(\mathrm{p}<0,05)$. Histopatolojik olarak gruplar değerlendirildiğinde, CA1 bölgesinde $20 \mathrm{mg} / \mathrm{kg}$ tenoksikam kontrole göre nöronal hasarı arttıdığı, buna karsış1k dentat girus bölgelesinde $10 \mathrm{mg} / \mathrm{kg}$ ve $20 \mathrm{mg} / \mathrm{kg}$ tenoksikam nöronal hasarı anlamlı olarak azalttı ( $<<0,05)$.

Sonuç: Bu çalışma tenoksikam uygulamasının epileptik nöbetleri ve nöbet sonrası nöron hasarını doz bağımlı olarak azaltabileceğini göstermektedir.

Anahtar sözcükler: Epilepsi, Siklooksijenaz -2 inhibitörü, tenoksikam, pentilentetrazol

\section{INTRODUCTION}

Extensive experimental and clinical data show that activation of inflammatory pathways is a crucial factor contributing to the pathogenesis of seizures in diverse forms of epilepsy from different etiologies ${ }^{1-3}$. These data suggest an important role of inflammation on epilepsy development, known as epileptogenesis and the and including the initiation of seizures ${ }^{1,2,4,5}$. In addition, several anti-inflammatory drugs have been reported to exert antiepileptic actions ${ }^{1,2,5}$. On the contrary, there are inverse data have been declared about the relation between inflammation and epilepsy. Therefore, more studies are needed to fully understand this relation ${ }^{5}$.

Cyclooxygenase (COX) is the rate-limiting enzyme in PG synthesis and is a major target of nonsteroidal anti-inflammatory drugs ${ }^{4}$. Local signaling is necessary to generate of new neuronal or glial cells within the central nervous system $^{6}$. Microenvironment changes, damage and/or inflammation may effect cell differentiation and proliferation ${ }^{6}$. There are two COX isozymes have been identified: COX-1 and COX-2. COX-1is constitutively expressed in almost all tissue types whereas COX-2 is highly regulated by different endogenous and exogenous signals $^{6}$ and predominantly expressed isoform in the brain ${ }^{9}$. The specific inhibitor of COX-2 has been shown to protect against epileptogenesis and neuronal damage in experimental rat models ${ }^{4,7,8}$. Although little is known about how the COX-2 mechanism regulates neuronal signaling in epileptogenesis, applied COX-2 inhibitors are claimed to have anti-epileptogenic and neuroprotective effects in experimental models ${ }^{9}$. Today, tenoxicam, a nonsteroidal anti-inflammatory drug, is rather frequently prescribed because it is a selective inhibitor of COX-2 ${ }^{10,11}$.

The present study aimed to investigate the effects of tenoxicam on pentylenetetrazoleinduced seizures and to demonstrate the neuroprotective effect of tenoxicam on neuronal damage after pentylenetetrazole administration. Our results show that dose-dependent administration of tenoxicam might have a protective effect to reduce epileptic seizures and post-seizure neuron damage.

\section{MATERIALS AND METHODS}

\section{Experimental Animals}

All experimental protocols were performed in accordance with the guidelines for the local ethics committee on the care and use of animals. All mice were housed and bred $12 \mathrm{~h}$ light $/ 12 \mathrm{~h}$ darkness in polypropylene cages and in a temperature of $20-22^{\circ} \mathrm{C}$, with free access to both food and water. 18 Wistar albino adult male rats $(220 \pm 20 \mathrm{~g})$ were used.

\section{Drug administration}

Tenoxicam were dissolved in physiological saline. Solutions were freshly prepared on the days of the experiments.

\section{Experimental procedure}

Eighteen rats were divided randomly into three groups for behavioral and histological assessments. Group 1 was given saline intramuscularly (i.m.), group 2: $10 \mathrm{mg} / \mathrm{kg} / \mathrm{day}$ tenoxicam (i.m.), and group 3: $20 \mathrm{mg} / \mathrm{kg} / \mathrm{day}$ tenoxicam (i.m.) for ten days. The tenth day, 
pentylentetrazol (PTZ) $(70 \mathrm{mg} / \mathrm{kg})$ was injected intraperitoneally $45 \mathrm{~min}$ after last tenoxicam injection to induce seizures. Racine's Convulsion Scale (RCS) were used to evaluate the seizures stages as follows: $0=$ no convulsion; $1=$ twitching of vibrissae and pinnae; $2=$ motor arrest with more pronounced twitching; $3=$ motor arrest with generalized myoclonic jerks; $4=$ tonic-clonic seizure while the animal remained on its feed; $5=$ tonic-clonic seizure with loss of the righting reflex; and $6=$ lethal seizure. Rats were observed for both to evaluate Racine's Convulsion Scale (RCS) and to record first myoclonic jerck (FMJ) onset times which coincide inception stage ${ }^{12}$. The observation period for PTZ-induced seizures was limited to $30 \mathrm{~min}$ in duration ${ }^{13}$. Two hours after, the animals were terminated using the decapitation method and brain tissues were removed.

\section{Histopathological evaluation}

Formalin-fixed brain sections $(4 \mu \mathrm{m})$ were stained with toluidine blue stain to quantify the number of dark neurons. All sections were examined and photographed with Olympus BX51 microscope. Dark neurons and survival neurons were counted in six sections per studied animal ( $\mathrm{n}=6$ for each group) in the Image $($ Fiji) program (Rasband, W.S., ImageJ, U. S. National Institutes of Health, Bethesda, Maryland, USA, 1997-2014). The number of dark neurons were given as percentage (toluidine blue stained neurons $* 100$ /survival neuron). The observers blinded to the study groups accomplished all histological assessments.

\section{Statistical analysis}

The results were expressed as a mean \pm standard error of mean (SEM). The data analyses were performed with SPSS Version 21.0 for Windows. The RCS score, FMJ time and dark neurons were evaluated using a one-way analysis of variance (ANOVA). A post hoc Tukey test was utilized to identify the differences between the experimental groups, and a value of $p<0.05$ was accepted as statistically significant.

\section{RESULTS}

\section{Evaluation of groups in terms of RCS and FMJ onset times}

When the Racine scores were calculated between the groups, there were statistically significant differences between the saline $(5.5 \pm$ $0.2)$ and $10 \mathrm{mg} / \mathrm{kg}(4.3 \pm 0.4)(\mathrm{p}<0.05)$ and there were no statistically significant differences between $20 \mathrm{mg} / \mathrm{kg}$ tenoxicam (5.5 \pm $0.2)$ and saline $(p>0,05)$. In addition, differences between the $10 \mathrm{mg} / \mathrm{kg}$ tenoxicam and $20 \mathrm{mg} / \mathrm{kg}$ tenoxicam were significant statistically $(\mathrm{p}<0.05)$ (Fig.1).

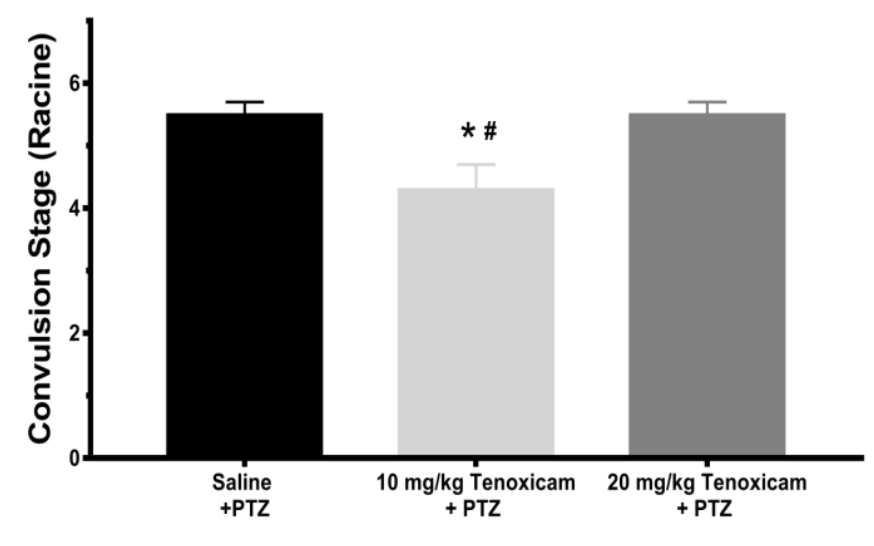

Figure 1 Racine Convulsion Scale, Data are presented as mean $\pm \mathrm{SEM} .{ }^{*} \mathrm{p}<0.05,10 \mathrm{mg} / \mathrm{kg}$ tenoxicam $+\mathrm{PTZ}$ group compared with saline + PTZ. ${ }^{\mathrm{p}}<0.05,10 \mathrm{mg} / \mathrm{kg}$ tenoxicam + PTZ group compared with $20 \mathrm{mg} / \mathrm{kg}$ tenoxicam + PTZ group. 
There were statistically significant differences $(\mathrm{p}<$ $0.01)$ between saline group $(39,3 \pm 6.3 \mathrm{~s})$ and 10 $\mathrm{mg} / \mathrm{kg}$ tenoxicam $(87,3 \pm 12 \mathrm{~s})$ group in terms of FMJ onset times. On the contrary, there were no statistically significant differences between 20 $\mathrm{mg} / \mathrm{kg}$ tenoxicam $(51,5 \pm 2,5)$ and saline group in terms of FMJ onset times ( $p>0.05$ ). In addition, there were differences between $10 \mathrm{mg} / \mathrm{kg}$ tenoxicam and $20 \mathrm{mg} / \mathrm{kg}$ tenoxicam statistically $(\mathrm{p}<0,05)$ (Table 1).

Table 1. Fist myoclonic jerk (FMJ) onset time as seconds(s). Data were expressed as mean \pm SEM. *p $<0.01$ comparedto PTZ-saline group. ${ }^{\mathrm{p}}<0,05$ compared to PTZ and $20 \mathrm{mg} / \mathrm{kg}$ tenoxicam group

\begin{tabular}{|l|l|}
\hline Groups & \multicolumn{1}{|c|}{ FMJ onset time(s) } \\
\hline PTZ (70 mg/kg) and saline (group 1) & $39,3 \pm 6.3$ \\
\hline PTZ (70 mg/kg) and $10 \mathrm{mg} / \mathrm{kg}$ tenoxicam (group 2) & $87,3 \pm 12^{* \#}$ \\
\hline PTZ (70 mg/kg) and $20 \mathrm{mg} / \mathrm{kg}$ tenoxicam (group 3) & $51,5 \pm 2,5$ \\
\hline
\end{tabular}

\section{Evaluation of groups in terms of dark neurons}

There are varied criteria used to identify the dark neurons, contains neuronal shrinkage, nuclear pyknosis, chromatin aggregation, intense (dark) staining of perikaryal, dendritic and axonal cytoplasm, and surrounding spongiosis in hippocampal formation (Fig. 2). Administration of tenoxicam at the dose of $10 \mathrm{mg} / \mathrm{kg}$ significantly prevented production of dark neurons due to PTZ induced seizures in DG regions of hippocampus $(\mathrm{p}<0.05$; Fig. 3A) but did not significantly prevent production of dark neurons in CA1 regions of hippocampus (p>0,05; Fig. 3B). Also $20 \mathrm{mg} / \mathrm{kg}$ tenoxicam significantly decreased dark neurons in DG region of hippocampus ( $\mathrm{p}<0,05$; Fig. 3A) but interestingly increased dark neurons in CA1 region of hippocampus ( $\mathrm{p}<0,05$; Fig. 3B). In addition, there was significant difference between at the dose of $10 \mathrm{mg} / \mathrm{kg}$ and at the dose of $20 \mathrm{mg} / \mathrm{kg}$ tenoxicam in CA 1 and $D G$ regions of hippocampus in point of dark neurons ( $p<0,05$; Fig. 3. A-B).

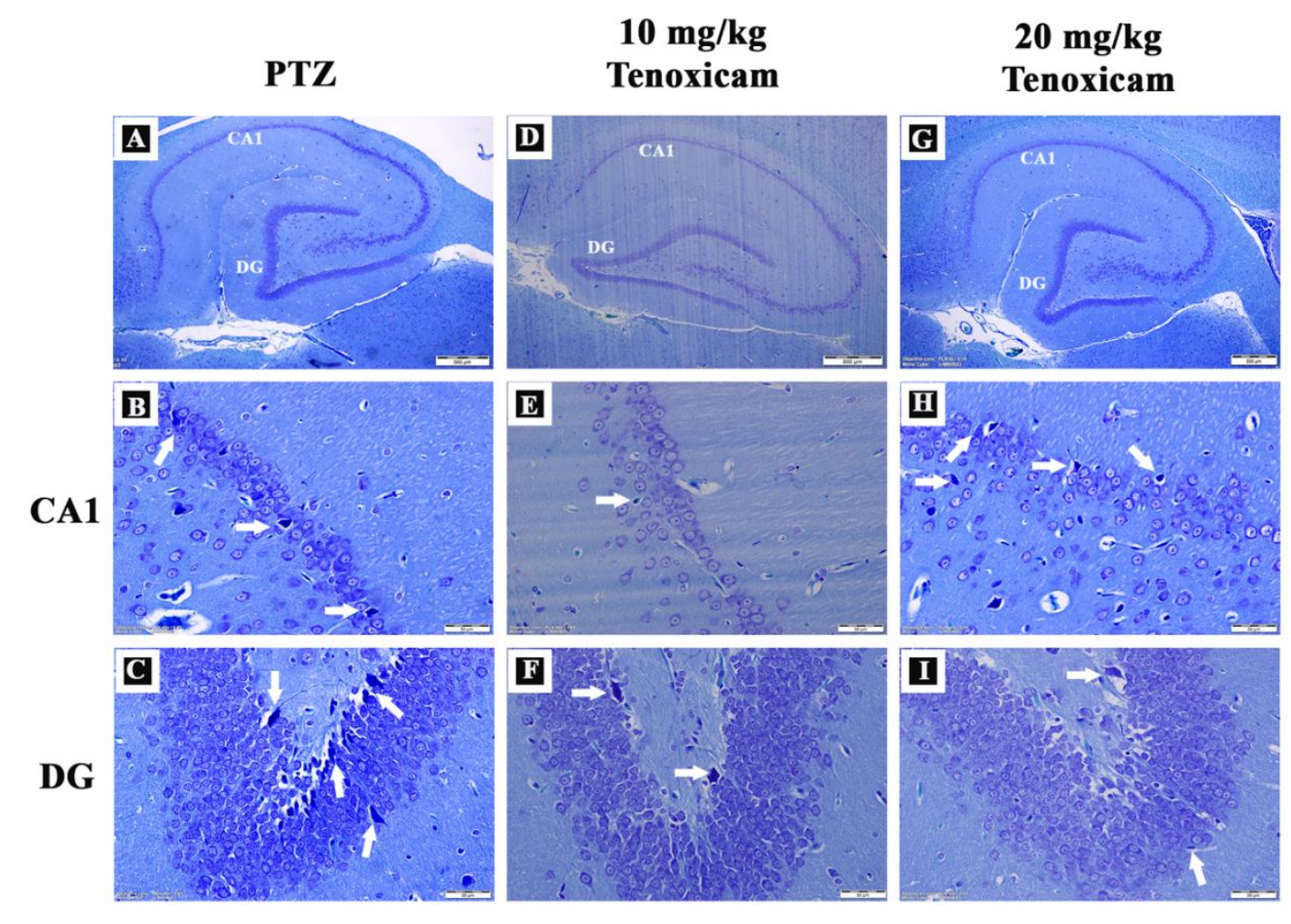

Figure 2 Toluidine blue staining of coronal hippocampus sections are showing the different areas of the hippocampal formation; Cornu Ammonis 1 (CA1) and dentate gyrus (DG) regions. A-C; PTZ group. D-F; 10 mg/kg Tenoxicam group. G-I; $20 \mathrm{mg} / \mathrm{kg}$ Tenoxicam group. Dark neurons are presented with arrows among pyramidal cells in CA1 and DG regions. 
A

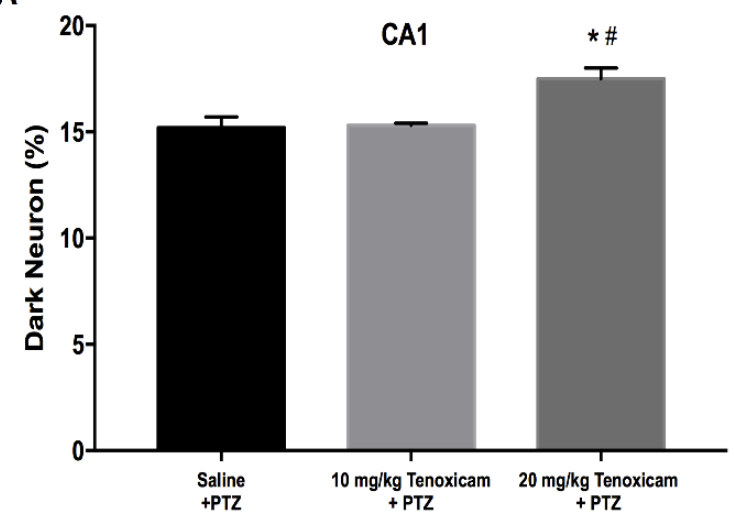

B

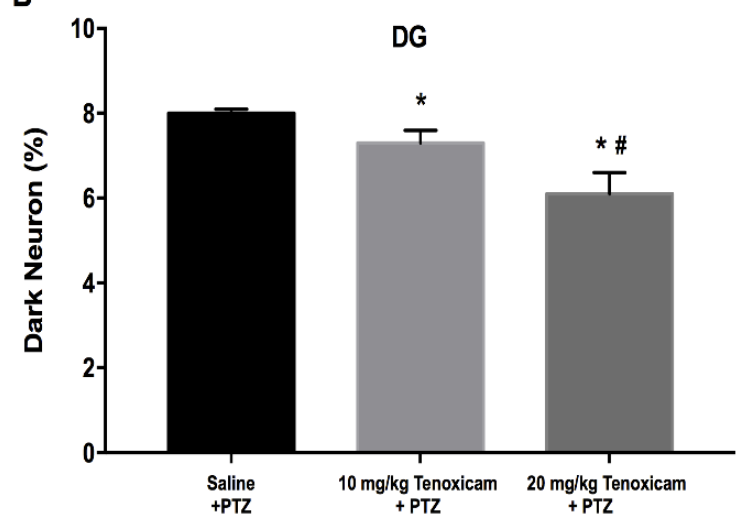

Figure 3 Comparison of dark neuron numbers per area in CA1 (A) and DG (B) areas between groups. Data are presented as mean $\pm \mathrm{SEM} . * \mathrm{P}<0.05$ in comparison with control group. ${ }^{*} \mathrm{P}<0.0520 \mathrm{mg} / \mathrm{kg}$ tenoxicam+PTZ compared to $10 \mathrm{mg} / \mathrm{kg}$ tenoxicam+PTZ.

\section{DISCUSSION}

Various studies in different animal models of epilepsy and epilepsy patients with hippocampal sclerosis have shown that COX-2 expression was induced after seizures ${ }^{6,}{ }^{14-17}$. Furthermore, the concentrations of prostaglandins (PGs) increased in the cerebrospinal fluid of epilepsy, hippocampal sclerosis and febrile seizures patients ${ }^{18}$. In the present study, chronic administration of low dose tenoxicam significantly decreased $\mathrm{RC}$ and also increased FMJ but this effect disappeared at high dose. This suggests that the activation of COX-2 has a central role in the genesis of epilepsy, as well in the pathways targeted by new anti-epileptogenic drugs.

Moreover, COX-2 expression regulates prostaglandin E2 $\left(\mathrm{PGE}_{2}\right)$ synthesis, which plays crucial role in synaptic signalling during seizures and was detected high level in the cerebrospinal fluid of patients with epilepsy, hippocampal sclerosis and febrile seizures ${ }^{6}$. Several COX-2 selective inhibitors such as nimesulide, parecoxib, rofecoxib, NS-398, SC-58125 etc., have been tested in experimental epilepsy models ${ }^{19}$. Published data indicate that the effects of COX-2 inhibitors are contradictory in epileptic animal models. Some previous researches showed that the drugs that inhibit COX-2 activity such as nimesulide and indomethacin treatment played an anticonvulsant role and reduced hippocampal cell death in experimental epilepsy models ${ }^{15}, 17,18$. Using SC-58125, a specific COX-2 inhibitor, inhibited the upregulation of inflammatory cytokines and reduced COX-2 and $\mathrm{PGE}_{2}$ levels and neuronal apoptosis ${ }^{20,21,22}$. On the contrary, using another selective COX-2 inhibitor NS-398 generated proconvulsant effects and increased neuronal mortality and damage in mice ${ }^{23}$. In this study, pretreatment with tenoxicam significantly decreased the stage and duration of pentylentetrazole-induced seizures.

On the other hand, in this present study showed that after PTZ-induced seizures damage to hippocampal neurons of the rats were prevented by tenoxicam as previous studies, which were treatment with different COX-2 inhibitors ${ }^{6,20-24}$. In addition, the results of this present study showed that PTZ-induced seizures were resulted in dark neuron production in the hippocampal regions, as observed by previous studies 25,26 . The affected neurons, which are distributed among the healthy neurons and microenvironment, are called dark neurons ${ }^{27}$. Initially, although dark neurons were thought to be histological artifacts in neurosurgical biopsy specimens, it was later noticed that they were formed after brain trauma ${ }^{28}$. Dark neurons have characteristic features such as basophilic appearance and morphological changes and have been shown in hypoglycemia, ischemia, stress, as well as in epilepsy ${ }^{29}$. It is suggested that depolarization, glutamate release or receptor activation are more efficient in the mechanism of dark neuron production ${ }^{27}$, in addition, epilepsy is also an important cause of dark neuron production 26, 27-29. There are many reports that confirmed hippocampal damages caused by seizures $26,30,31$. The results of this study were consistent with previous studies showing that dark neurons were produced in brain tissues following PTZ-induced seizures. 
The results of the present study showed that low dose of tenoxicam decreased epileptic seizures as well as preventing neural damage after PTZinduced seizure in rats. These results support the beneficial effect tenoxicam on the nervous system. Further studies are required for determining the mechanism of tenoxicam on this effects.

\section{REFERENCES}

1. Vezzani A, Granata T. Brain inflammation in epilepsy: experimental and clinical evidence. Epilepsia. 2005; 46: 1724-43.

2. Vezzani A, Baram TZ. New roles for interleukin-1 Beta in the mechanisms of epilepsy. Epilepsy Curr 2007; 7: 45-50.

3. Choi J, Koh S. Role of brain inflammation in epileptogenesis. Yonsei Med J. 2008; 49: 1-18.

4. Takemiya T, Matsumura K, Yamagata K. Roles of prostaglandin synthesis in excitotoxic brain diseases. Neurochem Int 2007; 51: 112-20.

5. Rijkers K, Majoie HJ, Hoogland G, Kenis G, De Baets M, Vles JS. The role of interleukin-1 in seizures and epilepsy: a critical review. Exp Neurol 2009; 216: 258-71.

6. Zhang J, Goorha S, Raghow R, Ballou LR. The tissue-specific, compensatory expression of cyclooxygenase- 1 and -2 in transgenic mice. Prostaglandins Other Lipid Mediat 2002; 67: 12135.

7. Cole-Edwards KK, Bazan NG. Lipid signaling in experimental epilepsy. Neurochem Res 2005; 30: 847-53.

8. Kulkarni SK, Dhir A. Cyclooxygenase in epilepsy: from perception to application. Drugs Today 2009; 45: 135-54.

9. Polascheck N, Bankstahl M, Löscher W. The COX-2 inhibitor parecoxib is neuroprotective but not antiepileptogenic in the pilocarpine model of temporal lobe epilepsy. Exp Neurol 2010; 224: 219-33.

10. Van Antwerpen P, Neve J. In vitro comparative assessment of the scavenging activity against three reactive oxygen species of non-steroidal antiinflammatory drugs from the oxicam and sulfoanilide families. Eur J Pharmacol 2004; 496: 55-61.

11. Naziroğlu M, Uğuz AC, Gokçimen A, Bülbül M, Karatopuk DU, Türker Y, Cerçi C. Tenoxicam modulates antioxidant redox system and lipid peroxidation in rat brain. Neurochem Res 2008; 33: 1832-7.

12. Racine RJ. Modification of seizure activity by electrical stimulation. II. Motor seizure. Electroencephalogr Clin Neurophysiol 1972; 32: 281-94.

13. Uyanikgil $\mathrm{Y}^{1,2}$, Özkeşkek $\mathrm{K}^{3}$, Çavuşoğlu $\mathrm{T}^{1,2}$, Solmaz $\mathrm{V}^{4}$, Tümer $\mathrm{MK}^{5}$, Erbas $\mathrm{O}^{6}$ Positive effects of ceftriaxone on pentylenetetrazol-induced convulsion model in rats. Int J Neurosci 2016;126: 70-5.

14. Okada K, Yuhi T, Tsuji S, Yamashita U. Cyclooxygenase- 2 expression in the hippocampus of genetically epilepsy susceptible El mice was increased after seizure. Brain Res 2001; 894: 3325.

15. Tu B, Bazan NG. Hippocampal kindling epileptogenesis upregulates neuronal cyclooxygenase-2 expression in neocortex. Exp Neurol 2003; 179: 167-75.

16. Kawaguchi K, Hickey RW, Rose ME, Zhu L, Chen J, Graham SH. Cyclooxygenase-2 expression is induced in rat brain after kainate-induced seizures and promotes neuronal death in CA3 hippocampus. Brain Res 2005; 1050: 130-7.

17. Dhir A, Naidu PS, Kulkarni SK. Effect of cyclooxygenase-2 (COX-2) inhibitors in various animal models (bicuculline, picrotoxin, maximal electroshock-induced convulsions) of epilepsy with possible mechanism of action. Indian J Exp Biol 2006; 44: 286-91.

18. Desjardins P, Sauvageau A, Bouthillier A, Navarro D, Hazell AS, Rose C, Butterworth RF. Induction of astrocytic cyclooxygenase- 2 in epileptic patients with hippocampal sclerosis. Neurochem Int 2003; 42: 299-303.

19. Du Y, Kemper T, Qiu J, Jiang J. Defining the therapeutic time window for suppressing the inflammatory prostaglandin E2 signaling after status epilepticus. Expert Rev Neurother 2016; 16: 123-30

20. Kunz T, Oliw EH. The selective cyclooxygenase-2 inhibitor rofecoxib reduces kainate-induced cell death in the rat hippocampus. Eur J Neurosci 2001; 13: 569-75.

21. Kawaguchi K, Hickey RW, Rose ME, Zhu L, Chen J, Graham SH. Cyclooxygenase-2 expression is induced in rat brain after kainate-induced seizures and promotes neuronal death in CA3 hippocampus. Brain Res 2005; 1050:130-7. 
22. Holtman L, van Vliet EA, van Schaik R, Queiroz CM, Aronica E, Gorter JA. Effects of SC58236, a selective COX-2 inhibitor, on epileptogenesis and spontaneous seizures in a rat model for temporal lobe epilepsy. Epilepsy Res 2009; 84: 56-66.

23. Baik EJ, Kim EJ, Lee SH, Moon C. Cyclooxygenase-2 selective inhibitors aggravate kainic acid induced seizure and neuronal cell death in the hippocampus. Brain Res 1999; 843: 118-29.

24. Polascheck N, Bankstahl M, Löscher W. The COX-2 inhibitor parecoxib is neuroprotective but not antiepileptogenic in the pilocarpine model of temporal lobe epilepsy. Exp Neurol 2010; 224: 219-33.

25. Karimzadeh F., Hosseini M., Mangeng D. Anticonvulsant and neuroprotective effects of Pimpinella anisum in rat brain. BMC Complement Altern Med 2012; 12: 76.

26. Seghatoleslam M, Alipour F, Shafieian R, Hassanzadeh Z, Edalatmanesh MA, Sadeghnia HR, Hosseini M. The effects of Nigella sativa on neural damage after pentylenetetrazole induced seizures in rats. J Tradit Complement Med 2015; 6: 262-8.
27. Baracskay P, Szepesi Z, Orbán G, Juhász G, Czurkó A. Generalization of seizures parallels the formation of "dark" neurons in the hippocampus and pontine reticular formation after focal-cortical application of 4-aminopyridine (4-AP) in the rat. Brain Res 2008; 1228: 217-28.

28. Mansouri S, Ataei ML, Hosseini M, Bideskan AR. Tamoxifen mimics the effects of endogenous ovarian hormones on repeated seizures induced by pentylenetetrazole in rats. Exp Neurobiol 201; 22: 116-23.

29. Kherani ZS, Auer RN. Pharmacologic analysis of the mechanism of dark neuron production in cerebral cortex. Acta Neuropathol 2008; 116:44752.

30. Pitkanen A., Tuunanen J., Kalviainen R., Partanen K., Salmenpera T. Amygdala damage in experimental and human temporal lobe epilepsy. Epilepsy Res 1998; 32: 233-253.

31. Salmenpera T., Kalviainen R., Partanen K., Pitkanen A. Hippocampal and amygdaloid damage in partial epilepsy: a cross-sectional MRI study of 241 patients. Epilepsy Res 2001; 46: 69-82. 